\begin{tabular}{l||l} 
& $\begin{array}{l}\text { Castern } \\
\text { European } \\
\text { Countryside }\end{array}$ \\
\hline DOI: 10.1515/eec-2017-0006 & $23^{\prime} 2017$
\end{tabular}

\author{
Despina Saghin, Elena Matei, Ioana Cojocaru, Gabriela Manea*, \\ Octavian Cocoş
}

\title{
The Hutsuls in South Bukovina: from Rural Tradition to Sustainable Development
}

\begin{abstract}
The Hutsuls, an ethnic group belonging to the Bukovina's agro-forestry and pastoral area, still preserve ancient folk traditions which generate friendly practices and attitudes towards the environment. Globalisation and modernisation have brought about changes in the local rural traditions which, on the one hand, threaten their singularity, and on the other hand, set the stage for a new start. The paper aims to analysethe perception of the Bukovina's communities on the tradition-sustainable development relations considered from a double perspective: the Hutsuls' traditions and the evolution of the group itself under changes in Romania in the last 25 years.

Consequently, our approach has sought to make a correlation between the information collected from the scientific literature, the answers given in a field survey and the opinions expressed in the media concerning this subject. The results of the study have shown that both the occupations and the traditions of the Hutsul ethnics, as well as their spiritual and cultural life, are strongly linked to the natural elements of the environment which the Hutsuls consider to be the basic resources for their existence. However, given that nowadays young people migrate abroad, the community's perception is indicative of a particular concern to do with the viability of this ethnic group; that is, the human right to
\end{abstract}

* Joins as the first author. ${ }^{*}$ Corresponding autho: gabrielamanea2002@yahoo.com 
turn to modernisation and the efficiency of multicultural policies application in Romania. The study is hence useful from several points of view: it can disseminate information on a national level concerning this little-known ethnicity; it can promote the role of the ethnic groups in reaching the local objectives of sustainable development; and it can supply the authorities with the necessary information for taking the right decissions, be they political, cultural, economic or demographic.

Keywords: Hutsuls, South Bukovina, sustainable development, traditions, rural, Romania.

\section{Introduction}

The Framework Convention for the Protection of National Minorities (1998) and the European Charter for Regional or Minority Languages (1998), stipulate that national minorities are cultural assets for every state, which is why they should be protected. Aside from a number of community provisions, the documents emphasise the need to increase and promote the necessary conditions for the preservation and development of their culture, language, traditions and religious identity, banning all forms of discrimination and all measures that might alter the demographic composition of an area to the detriment of minorities (European Council, 1995). As a member state of the European Union, Romania observes the rights and freedoms of national and ethnic minorities, according to the Romanian Constitution and the European legislation. The distribution of these ethnic groups on the Romania's territory mirrors the synergetic impact of the historical, cultural and economic factors, while their persistence over the time is explained, among others, by the endeavour to preserve their ethnocultural identity (Tîrcomnicu 2013).

According to the 2011 Population and Housing Census of Romania, minorities account for $10.4 \%$. The total number of Hutsuls is not published, as the Nomenclature of ethnicity and language (2011) includes Hutsuls (subcode 1403) in the Ukrainian group (code 1400) and thus the methodology counts them as Ukraineans. Moreover, many of them declared themselves also Romanians. Consequently, their number is hard to determine based on official documents, which is why we have had to turn to other studies concerning their life. Thus, according to Gheorghe Nimigeanu, the Hutsul 
population amounted to 14,348 people in 1945 (Iosep 1999), but in 1970 their number dropped to only 10,000 (Tufescu 1970).

The Hutsuls are an ethno-cultural group belonging to the Carpathian highlands, different from Boyko and Lemkos populations spreaded almost in the same region (Nikitin et al. 2009). Today, they live both in Romania (in the northern parts of the Suceva and Maramureş counties) and in Ukraine (in the historical province of Bukovina), forming a region named "Hutsulshchyna". Moreover, some could even be found in Poland and Slovakia (Figlus 2009). Their origin and name have been subjects of many debates, but despite the fact they have been associated with the Ukrainians (Soukand \& Pieroni 2016) and Ruthenians (Nistor 1915; Tufescu 1970) they consider themselves to be a freestanding ethnicity.

According to information provided by documentation, from the $17^{\text {th }}$ century the Hutsuls came from the Pokuttya Mountains ruled by Poland at that time and settled south of the Cheremosh Valley, in the [rare woods] belonging to the monasteries or in the areas inhabited by răzeşi [Romanian free peasants]. This process was only recorded in the documents of the Austrian administration in the $18^{\text {th }}$ century because the Hutsuls were not initially allowed to own the cleared lands, as the Moldavia's rulers granted this privillege only to the pământeni [autochtonous population] (Nimigeanu 1945). Despite the denial of this right, the Hutsuls continued to migrate in this area during the Austro-Hungarian administration from Galicia, having economic, military and religious reasons for doing so (Boboc-Cojocaru 2010). At the same time, migration was easy as the borders ceased to exist (Nimigeanu 1945).

Hutsuls' migration was gradual and sporadic; people came in small groups or as families in the mountain areas covered by branişti [rare woods] belonging to the monasteries Putna, Moldovița, Voroneț and, to a lesser extent, Sucevița (Iosep 1999). The number of Hutsul families increased in those communes lying on the upper valleys of Suceva (Izvoarele Sucevei, Ulma and Brodina), Moldova (Modova Sulița and Breaza), Moldovița (Moldovița and Vatra Moldoviței), Bistrița Aurie, Cârlibaba and Țibău (Cârlibaba). Their presence was also recorded in the branişte [rare wood] belonging to the Voroneț monastery, as well as in Ostra, Gemenea and Stulpicani which were three settlements situated in the Suha basin (Vasilcu 2006). The last recording made in 1943 showed that 9,942 Hutsuls lived in this area, respectively $64.4 \%$ of the total population (Nimigeanu 1945). 
The aim of the study has been to analyse the perception of the communities living in Bukovina of the relationship beween traditional and sustainable development, seen from a double perspective. The Hutsul traditions and the evolution of the ethnic group itself in the context of the last 25 years Romania's changes. In this respect, the objectives of our research are to highlight Hutsul's sustainable ethno-folkloric elements, which are specific to the Romanian village in Bukovina, and to analyse the effect of endogenous and exogenous perceptions on the Hutsul communities, taking into particular account the vulnerabilities connected to their ethnicity in the context of the globalization and changes of the Romanian society.

\section{Research Methods}

The study relies on a bibliographic research that takes into account both monographies and summary works, dealing with the national minorities and especially with the Hutsul one. At the same time, we reviewed the national and European legislation regarding the minority groups and studied thoroughly the sustainable development theoretical and applicative strategies. Based on the bibliographic data corroborated with the obervations in the field, we have been able to come up with a map showing the spatial distribution of this ethnic group over the Suceava County's territory (Fig. 1).

To study how local people perceive Hutsul ethnicity, but also to collect information about the rural reality of this community, we have applied a survey using the interview and the snowball sampling technique. This is because people become more receptive to a researcher when the latter has been vouched for by a friend as trustworthy. The interviewes were applied in twelve villages populated by hutsuls, mostly grouped on Modovița and Suceava Valleys, and less on Modlova and Bistrița, in February 2016. The sample dimension was established by taking into account the usual requirement of studies to work with different numbers of interviews (Morse 1994; Bernard 2000; Bertaux 1981). 
Figure 1. The settlements in the Suceava County that are populated by Hutsul ethnics

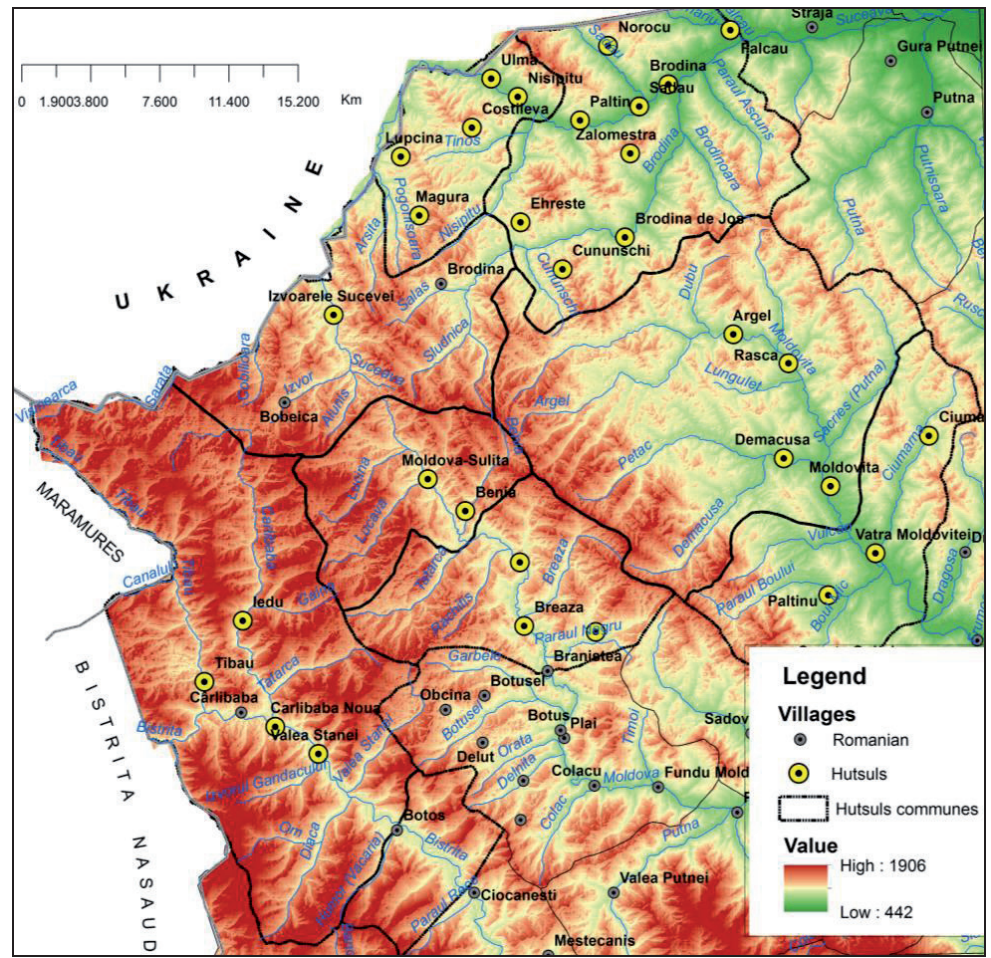

However, regardless of the type of qualitative research, 15 is the smallest acceptable limit (Adler \& Adler 1994). On the other hand, the number of respondents in social science research should be at least 12 to 60 or at least 6 (Guest et al. 2006), depending on data saturation. On the basis of this account, we based our research on 18 people, validated from the initial 20. Among $75 \%$ are Hutsuls, amost equal in gender and grouped in three generations as the following: 22.2\% aged between 18 and 24; 24.3\% over 60 and $66.5 \%$ between 25 and 59 years old to capture specific points of view. All the people have given us their consent for processing the interviews, which is why, in terms of respecting their privacy, all documents were coded (Matei et al. 2013) using the following symbols: " $H$ " for Hutsuls, "R" for Romanians, "f" for female, " $m$ " for male, while for their age we used the corresponding numbers, without giving the name of the villages in which they live, just the river valley. 
At the same time, we have monitored the social media, which have been broadly defined to refer to "' (Murthy 2013). We hve also nterrogated the sites with opinions and comments about the origin and customs of the Hutsul minority, as this is a useful tool for recording the endogenous and exogenous perception of an ethnicity that is relatively little known by the Romanian population.

\section{Results and discussion \\ Sustainable development attitudes reflected by the occupations of the hutsul minority in South Bukovina}

Hutsuls belong to the mountain typology, as they have turned to economic activities supported by simple occupations, sometimes even primitive, which have been for generations in harmony with the environment and the resources it provides (forests and pastures). They have their own knowledge and skills related to animal husbandry (especially cattle, sheep and horses), but also to wood harvesting and wood processing.

The rural landscape is, amongst others, the expression of a type of attachment to domestic animals. Conventional transhumace has changed because, during the cold season, the animals are kept within the household, while in summertime they are brought into sheepfolds to take advantage of the mountain and subalpine grasslands. Thus, the cattle and the sheep are cared for by shepherds who, in most cases, are also sheepfold organisers. The Hutsuls who own lands in the vicinity of their households turn them to account during the summer season through grazing. The animals, especially the cattle, are kept overnight in temporary shelters called şuri [barns].

Although the population is elderly, the number of animals kept in one's farm is still large, except for the Huțul horse, a well-known autochtonous race, specific for the Oriental Carpathians, very resistant for the difficult mountain routes and very useful for wood harvesting. The special connection between the Hutsuls and the animals is revealed by the practices and customs they exhibit during the great religious holidays of the year, when the animals are sprinkled with holy water, carefully nourished and groomed or even left loose. The authors witnessed this practice on Saint Charalambos holiday, celebrated on February 10, when Hutsuls go to the church to consecrate the bran and flour, which they later give to the animals when these are ill. 
Another celebration carefully observed, especially by the elder Hutsuls who deal with livestock, is Saint Vlasie (February 11), who is believed to protect people against weasel (Mustela nivalis) bite. From the applied questionnaires, one can see that people are afraid of the natural threats and they believe that these can be alleviated by faith or religious practices: In stormy weather, we light the candle consecrated on St. Charalambos holiday, to keep thunder and lighting away from our home $\left(\mathrm{H}_{\mathrm{f} 21}, \mathrm{H}_{\mathrm{f} 54}\right)$.

Another traditional activity that highlights the connection existing since ancient times with the forest environment is wood harvesting. We can notice an emotional tie between the Hutsuls and the forest. Traditionally, woodcutters worshipped the tree that was to be cut and begged foregiveness for their deed and shows a subtle religiosity, doubled by temperance, even though almost all the household items and the furniture were made of wood by the householder. Wood processing was an occupation specific for Hutsul males, focused on carpentry, woodwork and the construction of wood houses, along with the art of woodcarving,.

In contrast, the Hutsul women were in charge of various rural activities: housekeeping, the processing and spinning of wool and hemp and canvas weaving, which was used for manufacturing the traditional clothing products, carpet and rug manufacturing, etc. As many of them have adopted conventional clothing, keeping some elements (headkerchief, fur cap, waistcoat), the complete traditional/festive costume is on the verge of extinction: "For the cultural exchanges in the country and in Ukraine we had to borrow old costumes" $\left(\mathrm{H}_{\mathrm{f} 75}\right)$. At present, there are no workshops or households to preserve the art of sowing and weaving the traditional costumes.

Hutsuls have a good knowledge of medicinal herbs and of the food resources of their natural environment (forest) (Soukand \& Pieroni 2016). They claim to be the first who prepared several products among which the cranberry stum is known for its special curative and nutritious effects. Agriculture is less developed because arable lands are scarce, fertility is low and climate conditions are harsh. People usually grow potatoes, barley, oat and buckwheat.

The preservation of these traditions might be judged as an attribute of isolation and poverty. It has a lot in common with the systemic vision of the planet, which advocates the use of local materials to diminish the negative effects induced by transport and power production activities. At the same time, this approach gives the people the chance to obtain safe natural 
products. The family passes the traditions to the new generations: " $H_{f 21}$ "I've learned from my parents by watching and doing"; $H_{f 61}$ "Nobody compels the Hutsuls to preserve their customs; they learn them... from one another".

The attraction to the forest environment with all its fauna resources has stirred within the Hutsuls' souls the hunting sense and the passion for weapons. All households possess hunting weapons like ax, hatchet and various traps made of brass. Although poaching occurs frequently ("I have heard that people deal with poaching, but they take only what they need", $\mathrm{H}_{\mathrm{f} 57}$ ) hunting is practiced rationally, with the purpose of providing for one's family needs, without trespassing on their hunting laws. Poroşneața, an accessory worn by men, is composed of a belt that holds a container made of goat horn or antlers used for storing the gunpowder is indicative of the Hutsuls' disposition for weapons and hunting. Finding antlers or goat horns is another secret of this ethnic group. These are sold on the black market, used as decorative objects or turned into raw material for making "antler tablets", saltcellars and buttons for clothes.

An element of pride is inchistritul ouălor [Easter eggs painting]. Hutsuls say that this custom-occupation, which has been assimilated by the entire population in Bukovina, is specific for their ethnicity. They present as arguments the specific decorative elements of this art: the antlers, the Heaven's Stairway, the shepherd's wand, manica [a red flower], the plow, the rake, the fish, the lost path, etc. (Fig. 2) and the tool employed for this craft, called chişiţă [a kind of needle used for painting]. In the Hutsuls' mind, the egg is a symbol of the sun. In the past, people used natural dyes and bee wax, while the predominant colours were black, mauve and blue.

Today, Easter egg painting has spread to every Moldova region, using emptied pieces. At present, the Hutsuls have adapted this craft to the market economy because Easter painted eggs are sold with the occasion of tourist or agricultural fairs like, for instance, the Egg Fair organised in Suceava City. Several Hutsul ethnics have dispatched the eggs to the museums $\left(\mathrm{H}_{\mathrm{f} 57}\right)$, while others develop their own centres for selling souvenirs in their households, especially in the villages with tourist potential $\left(\mathrm{H}_{\mathrm{f} 64}\right)$. 
Figure 2. Hutsul designs on Easter painted eggs. Photo: Cojocaru Ioana, 2016.

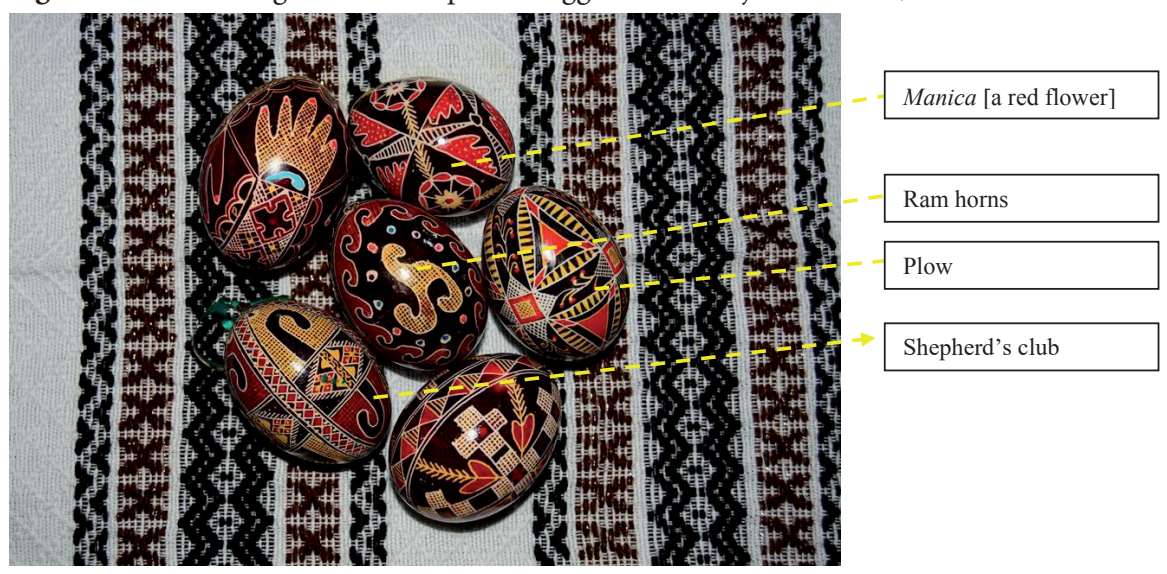

We have observed something of an adaptation of Hutsuls to a market economy, even if only sporadically. Some families are involved in tourism activities by renting horses for rides or by supplying homespun fabrics that will be sold as souvenirs ("I weave in the house for my daughter and she makes souvenir purses", $\mathrm{H}_{\mathrm{f} 75}$ ).

We did not notice the same "adjustment" or acceptance of the migration phenomenon affecting the young people who have gone in search of work in other European states. Under these circumstances, the elders think it impossible to pass on to them this tradition, but the young interviewees have claimed that they knew all the secrets of the occupations ("I know to do anything in the house" $-\mathrm{H}_{\mathrm{m} 18}$ ). Some of them learned them within the family, while others had been involved in programmes initiated by schools, townhalls or ethnic associations.

\section{Integration of Dwelling and Housing in the Natural Environment}

The Hutsuls' ancestors used to build their houses depending on the resting place of their cattle. Later, the houses began to form a core on valley bottoms. Consequently, the traditional Hutsul household is now extinct. While it still existed, it resembled a fortress surrounded by massive fences, made up of thick fir beams, $20 \mathrm{~cm}$ in diameter, placed horizontally and covered by wood shingle roofs disposed on two levels. The courtyard was closed by large 
gates equipped with a round or square roof, depending on their size. The household's oldest element was the house, the roof of which was extended at the back to form a shelter for the cattle.

With the passing of time, people built stables in the courtyards and barns as far as $200 \mathrm{~m}$ away from the house $\left(\mathrm{H}_{\mathrm{f} 75}\right)$. The other components that made up the household were the following: the warehouse, the cellar, the woodshop and the larder, called, which served as a deposit for food and clothing. The roofs were made of wood shingle, fir or spruce, $1.5-2 \mathrm{~m}$ long and $15-20 \mathrm{~cm}$ wide, having a durability of more than 50 years. The windows of the houses were small and separated into four panes by a wooden cross, which was meant to cast out evil spirits because the Hutsuls were very superstitious people, believing in spells, curses and incantations.

On the inside, the traditional houses were divided in three chambers: horomi [vestibule], room and larder. The stove in the main room was very important. It was built in the corner lying between the vestibule's wall and the exterior one, occupying nearly half of the room and concentrating around it most of the necessary tools for cooking. Near the stove was the bed, which was used for resting and for storing clothes. In the corner opposite to the one with the stove were the table and the benches, whereas in the corner next to the door was blidarul [the dish shelf].

The walls, which were made of wood beams padded with moss, are nowadays painted in white and adorned with pictures, rugs, lăicere [wool carpets], towels and the habitual religious icons, placed on the eastern side. The basic furniture in the Hutsuls' houses and the indispensable inventory (ciubere [tubs], bărbânțe [wooden staves recipients], budace [wooden vessels used for curdling milk], cofe [wooden vessels for storing milk or water], ploşti [wooden flasks], hope chests, and pipes) were also made of wood. In older times, but less and less today, wooden storing vessels were largely used for milk processing, another occupation that the Hutsuls have mastered very well.

The women's items included the loom (Fig. 3) and the wool-working tools (the spinning wheel and the distaff), by which they used to weave or knit to meet the needs of their housholds or, as it happens today, to supply the souvenir shops with semi-worked materials (“'”- $\mathrm{H}_{\mathrm{f} 75}$ ). Currently, the Hutsuls use local materials (river rocks, wood) for building their houses, burn wood for heating (which is a renewable resource), and decorate the interior of their homes with stitched organic fabrics, as well as wood, horn or bone carvings. 
Many domestic activities are accomplished by local cooperation, the socalled clacă [collective work]; however, their approach is less practiced than in the past.

Figure 3. Loom in a Hutsul household used for folk costumes pieces. Photo: Matei Elena, 2016

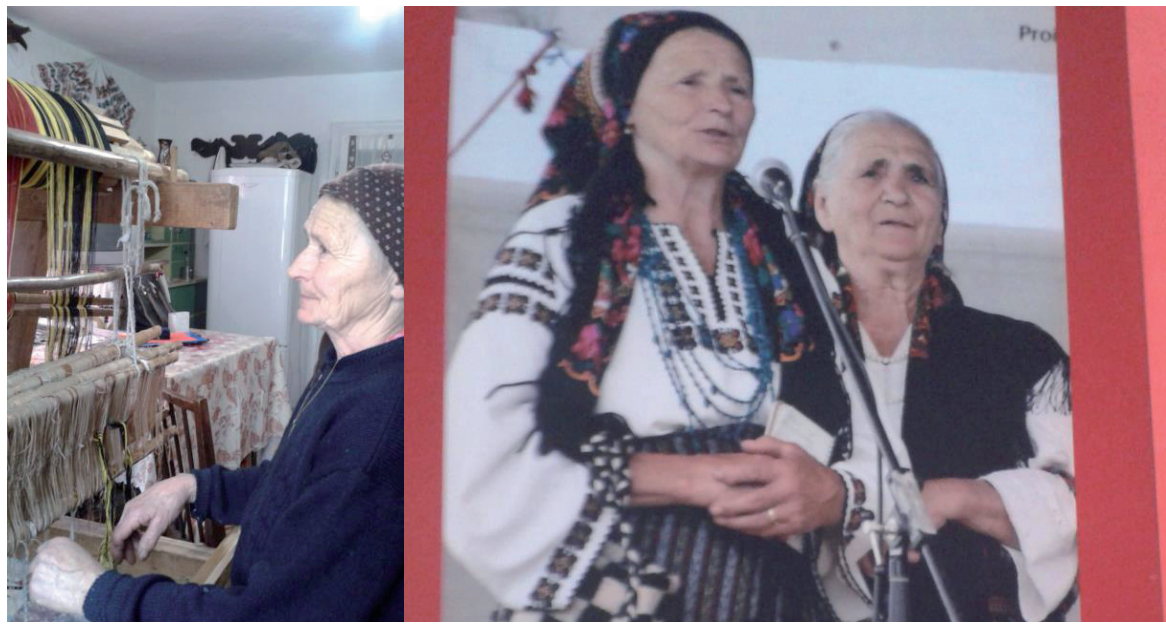

The Hutsul gastronomy is based on common food products obtained in one's household or gathered from the woods, generally rich in calories, to support the intense physical effort and the climatic stress (Table 1). Three staple food items govern their gastronomy; namely, meat, milk and potato. Their preference for potato, which is an important feed for pigs, is often invoked by the Hutsuls when they describe the interethnic verbal tensions ("Many times we are called pigs", $\mathrm{H}_{\mathrm{f} 57}$ ). However, life expectancy is similar to the rest of the people living in the mountain areas.

The Hutsuls' spiritual culture encompasses countless traditions and customs connected with the Christian holidays and the main events of the human life cycle, all of them strongly related to the natural elements of the belief system. Hutsul people came and remained orthodox. They belong to Christian Orthodox Church and strictly observe the holidays according to the Old Style (the villages along the Moldova Valley with services in Slavonian) or to the New Style since the "great schism" (1924), which brought a shift from earlier 13 days in the calendar of religious events (Irimie 2014) and services in Romanian (the villages along the Moldovița Valley). Some 
spiritual practices, although akin to the Romanian ones, are considered by the interviewees to be specific for this ethnic group. Their preservation in church and in the family is an element of ethnic sustainability and identity.

Table 1. Hutsuls' specific dishes

\begin{tabular}{|c|c|c|}
\hline No. & Name $^{*}$ & Explanation \\
\hline 1 & Bujinițea & Meat (smoked on the premises) with beans or pickled cabbage \\
\hline 2 & Culeşa barabulina & Potato polenta \\
\hline 3 & Huslinka & Mixed sour milk (sheep and cow) \\
\hline 4 & Ieşniţea & Scrambled eggs, cracklings of pork fat and cream \\
\hline 5 & Rosâu îs capustii & Sauerkraut juice with polenta (eaten during the fast) \\
\hline 6 & Povedlo & Jam \\
\hline 7 & Pşeneția vareana & Boiled wheat \\
\hline 8 & Şuşeneții îs iabluc & Dry apple slices \\
\hline
\end{tabular}

* Dish names are phonetically transcribed in the Romanian language

Sustainability and Identity in the Spiritual, Social and Cultural Life

Christmas is an important holiday for the Hutsul community. The preparations begin on Saint Ignatius day when people sacrifice the pigs raised in their households and make up the Hutsul chişca [pig intestines stuffed with pork meat mixed with basil and corn flour]. On Christmas Eve, Hutsuls keep a total fast until sunset. They do not get annoyed, do not get angry, do not raise their voice and do not engage in evil actions $\left(\mathrm{H}_{\mathrm{m} 57}\right)$. On the same occasion, they organise a special feast, with twelve fasting food items intimating the twelve months of the year and the Twelve Apostles. The feast is made up of servings of canned or dry mushroom stew or salad, rolled cabage, boiled wheat with nuts, beans, peas, potato salad, pickled cabbage salad with onion and oil, rice, cheese pancakes, corn flour, dumplings, dry fruits cooked in syrup. All these foodstuffs are served in clay or wooden dishes. They are placed on a table on which people have previously placed a bunch of grass sprinkled with cloves of garlic, tied with a red thread in the sign of the cross for protecting the house against the evil spirits $\left(\mathrm{H}_{\mathrm{f} 57}\right.$ ? $\mathrm{H}_{\mathrm{f} 64}$, and $\mathrm{H}_{\mathrm{f} 21}$ ). On top of it, they lay out a tablecloth made of linen or hemp. Usually, the food is blessed by the parish priest (Romanian or Hutsul, in 
Romanian or Slavonian), who also blesses the believers' homes on Christmas Eve.

The houses are spread all over the place and it sometimes happens that the priest cannot reach all of them by sunset. In this case, the family members eat while being seated on benches, lest the cattle deliver their offsprings while standing. The master of the house, usually the husband, puts on another plate a little bit of each dish, then goes out and calls the wild animals to fast together with him, or else to refrain the next year from destroying the crops and the lands, as well as the flocks and herds $\left(\mathrm{H}_{\mathrm{f75}}, \mathrm{H}_{\mathrm{m} 80}\right)$. Although the interviewed Hutsuls stated that they still observed all these Christian ceremonial steps, other people thought differently ("along the Moldovița Valley, many people have embraced modern customs; only few families still preserve the traditions" $\left.\mathrm{R}_{\mathrm{m} 56}\right)$.

Upon completion of this ceremonial, people wait for the carolers. The community still preserves the custom of Religious Carols. Consequently, the male chorus of the local church goes to the people's households accompanied by a fiddler and by an artistic leader, the latter carrying the holy cross that he has received from the priest. The hosts reward the carolers with money, sausages, bacon, cereals and ringbread, while around the cross they place a towel of great artistic value, weaved or embroidered previously on homespun. It is common for the parish priest to confess and communicate the church choristers before going caroling door-to-door in the village. When they finish caroling, which can last until Epiphany, all things collected are divided among the carolers, in the presence of the priest, who receives part of the money, which he uses for the church needs $\left(\mathrm{R}_{\mathrm{m} 56}\right)$.

Herods tradition, a folk and religious form of drama, which is practiced by young people between Christmas and Epiphany is rather similar as that practiced by other Romanians and Europeans. The script is written by the priests or is transmitted orally from generation to generation.

On Christmas Eve, people perform the Pluguşorul [agrarian carol; = small plow] which, unlike the Romanian version, is sung not spoken. On St. Basil day, children go from door to door with Pşenița [seeding custom] and Sorcova [a kind of folk spell], in the first case reciting the verses while going around the house and in the second while staying inside and facing the religious icons. The master of the house collects the wheat spread by the children and mixes it with the one that is to be sown the next spring to enjoy the reach crops. 
On Epiphany's Eve, the villagers raise an ice cross near a spring or on the bank of a river crossing the settlement or in the churchyard. That same day, the priests go once again to the people's houses for offering blessings. On Epiphany day, the priest consecrates the river water, the ice cross and the wood vessels containing water by sinking in them basil and a wooden cross, brought in by the believers. After the service, the wells, the animals, the houses and the household annexes are sprinkled with holy water, while the cross is placed above the entrance door for protection. In fact, many Hutsuls celebrate the winter holidays longer than other people because those living in the South observe the New Style calendar and tend to visit their relatives in the north, who celebrate according to the Old Style calendar $\left(\mathrm{R}_{\mathrm{m} 56}\right)$.

During the St. George feast, people use to lay small turfs with yellow flowers () on the posts of the gates. Women are strongly influenced by superstitions, claiming that this practice wards off the evil spirits, charms, spells or curses that may befall people and households.

On Palm Sunday, believers go to church with sheaves of willow or birch catskins, which the priest then consecrates. When people return home, these are used for adorning the houses and the animal sheds to attract health and fertility.

The respect for the memory of the deceased can be seen in the first Saturday of the Lent, the so-called Sorocousti [Commemoration Day of the Dead], which is the last commemoration event of the Lent. On this occasion, people burn the vegetal residues and the wastes have resulted from the spring-cleaning of their households, which in their opinion will ", a world called. Apart from the religious significance, this practice helps the environment regain its vitality. While the residues burn, children jump through the smoke for purifying their body and soul in preparation for the Night of Resurrection.

On the Night of Resurrection, the Hutsuls go to church to attend a special service at the end of which the priest consecrates the foodbaskets prepared by the housewives and containing salt, garlic, butter, Easter painted eggs, bacon, Easter bread, plain bread and a braided candle. Forty days from the Easter, the Hutsuls, like all orthodox people, celebrate the Ascension, a feast known as Ispas (considered to be a witness of Jesus's ascension to Heaven), the Day of the Heroes, the Day of the Dead or Horse Easter. Here, the horses are fed with fine food over the course of an hour and afterwards are left loose for the remainder of the day. 
The Pentecost feast (Great Sunday or Pentecost Sunday), which the Hutsul minority calls Svita Nedilia [Holy Sunday] is celebrated with folk magical practices combined with religious elements. Rusaliile [Pentecost creatures] are supernatural beings embodied in evil old women, who are turned into ugly witches singing and dancing in the air, near the wells, on the hills or in the glades over the week before the Great Sunday. The tradition includes a three-day rest (Sunday, Monday and Tuesday) because it is believed that those who work in these days will be crippled or blinded. Thus, to safeguard their households, people place green twigs of lime, birch or beech on gateposts, on house's walls, as well as on barns and stables, which they will throw on fire during storms or whenever are threatened by other natural elements.

[Yellow Bedstraws], the holiday when Hutsuls celebrate the Birth of St. John the Baptist, which is also called [Floral John], is celebrated on 24th June, according to the present calendar, or 7th July, according to the old-style calendar. For Hutsuls, this day marks the end of hoeing works, the beginning of haymaking and the ripening of many medicinal herbs. The Yellow Bedstraws () gathered in bunches acquire magical connotations with different meanings. The girls tie them at the belt for their miraculous powers, lay them beneath the pillows the night before the feast hoping to dream the lads doomed to be their husbands, then throw the bunches on the roof to forsee their fate. Tradition says that if the bunch rests on the roof, then the respective girl will have a long and abundant life, but if it falls to the ground, she will experience a shorter and harder life. In the morning, people use to gather medicinal herbs, which are then brought to the church to be consecrated, thus acquiring healing powers.

Hutsuls are dominated by superstitions. The antidotes for preventing the occurrence of unwanted events are religious prayers, incantations and some other practices strictly observed so far. Thus, in summer, they have many more holidays than the Romanians: Saints Cosma and Damian on July 1; Saint Procopie, on July 8; and Pontilia [Saint Pantelimon], on $28^{\text {th }}$ July. Most of these superstitions are related to climatic and meteorological events and rely on the behaviour of some local fauna species (table 2:1-4).

Some people even admit the existence of black magic practices. The belief in demons and evil spirits is less frequent. However, women (MarianBălaşa 2013) create charms meant to stop the cows from giving milk (“”, $\mathrm{H}$ ${ }_{\mathrm{f} 57}, \mathrm{H}_{\mathrm{f} 62}$ ), cast curses, undo spells and use occult means to find their enemy, 
destroy his belongings or enhance their own fortunes. People also mention the use of various kinds of incantations meant to fight deochiul [the evil eye], rujia [rosacea] or mana vacii [cow's incapacity of giving milk].

Table 2. The Hutsuls' superstitions and rituals

\begin{tabular}{|l|l|l|l|}
\hline \multicolumn{1}{|c|}{ Name } & \multicolumn{1}{|c|}{ Period } & \multicolumn{1}{c|}{ Action/behaviour } & \multicolumn{1}{c|}{ Expected effects } \\
\hline 1.Green thursdays & $\begin{array}{l}\text { From the Holy } \\
\text { Thursday, the last } \\
\text { Thursday in the } \\
\text { Lent, until the } \\
\text { holiday. }\end{array}$ & $\begin{array}{l}\text { People are forbidden to } \\
\text { work the land. }\end{array}$ & $\begin{array}{l}\text { Hail will not fall, people } \\
\text { will be safe from storms, } \\
\text { floods and other disasters } \\
\text { that might ruin their crops. }\end{array}$ \\
\hline $\begin{array}{l}\text { 2. [Transfiguration } \\
\text { of Christ] }\end{array}$ & August & $\begin{array}{l}\text { Storks gather in flocks } \\
\text { and fly away. Storks linger } \\
\text { around and rotate for a few } \\
\text { days. }\end{array}$ & $\begin{array}{l}\text { Fall will be short and the } \\
\text { winter will be long and } \\
\text { and } \text { Winter will be short }\end{array}$ \\
\hline 3.Winter forecast & Summer-Fall & $\begin{array}{l}\text { Corn cob is covered with } \\
\text { several layers of husk. }\end{array}$ & $\begin{array}{l}\text { Winter will be long and } \\
\text { hard. }\end{array}$ \\
\hline 4.Winter forecast & Fall & $\begin{array}{l}\text { Birds nest on top of the } \\
\text { haystacks. }\end{array}$ & Winter will be hard. \\
\hline 5.Family difficulties & Whenever necessary & $\begin{array}{l}\text { The head of the family } \\
\text { worships the four corners of } \\
\text { the chamber }\end{array}$ & $\begin{array}{l}\text { Help from the protective } \\
\text { divinities of the house. }\end{array}$ \\
\hline 6.Deceased persons & Christmas, Easter & $\begin{array}{l}\text { Fill a glass with water and } \\
\text { a plate with fasting food or } \\
\text { sugar. }\end{array}$ & $\begin{array}{l}\text { Nourish the deceased who } \\
\text { return home. }\end{array}$ \\
\hline 8.Yew wood nails & $\begin{array}{l}\text { Christmas and } \\
\text { Easter }\end{array}$ & $\begin{array}{l}\text { Wonial } \\
\text { the house foundation. }\end{array}$ & Leads to family breakup. \\
\hline
\end{tabular}

\section{i) Incantation for rujia [rosacea]}

„Oi te rujia, ni buchi dujia, ni palai, ni focai, ni jile, ni vile, searțea radischi ni vidberai, projeannoii, moletveannoi Catrinii (the name of the person) scizai, propadai, scizne, propade. Pobilii ec craida, pociornii ec papir, prişlais îs lisa, ide u lis, prişlais îs polia ide u poli, prişlais na sleana, ide na toho holu şo ti 
pâslau. Ia tebea deviechimea vohniame jeveme vidpaliu, ni sama soboiu, îs Hospodom Svitem, îs Matcou Hrestoiu, îs Troițou nebeasnu.

Ikei hâski priişou Takei colaci naişou / (repeat three times) Ptiu! Şcizai propadai"/ (repeat three times)

„"/“Oh, rujia [rosacea], do not be strong, do not spread, do not hurt me, do not take away the joy from the faithful Catrina (the name of the person), go away and break your neck. Get chalk-white, black as burned paper, go away and disappear like foam on the water, like dew on the grass, you've come from the wood, go back to the wood, you've come from the field, go back to the field, you've been sent by someone, go back to your sender. I burn you with nine living flames, not alone, but together with the Holy God, the Mother of God and the Holy Cross.

Whatever disease has come, such ringbread has found (repeat three times)

Ptui! Perish from me!” (repeat three times)

ii) Incantation for mana vacii [cow's incapacity of giving milk]

„Pşica nenea, Pşica nenea. Ni na vaşe imne, na vaşu jetnischi setnia moloco, toustu smetanu, joutea maslo, joutea ec vâsc, zapaşnea ec vaselioc, solodchea ec mid, îs lisâu, îs rosâu, îs pşianeții, îs seroii zemneții şo vâd Boha naimenovano, vâd gazde, gazdenii zamenovano. Macovea zearno na cetvero rubaiu svoie ni puscaiu, ciujea ni chivaiu.

Ike hâski priişou Takei colaci naişou (se repeat three times)

Ptiu! Şcizai propadai!" (repeat three times)

"Pșica nenea, Pșica nenea (words used for calling the cow). It's not on your name, on your life, fat milk, fat sour cream, butter, as yellow as wax, smelling like basil, as aweet as honey in the woods, made from water, rye, wheat and crude earth, given by God, and offered by the householder and housewife. I split the poppy seed in two, what is mine I don't give up, I take nothing from the others.

Whatever disease has come, such ringbread has found (repeat three times) Ptui! Perish from me!" (repeat three times)

These feared evils can be banished by a belief in God, by wearing a cross, by sprinkling the face with holy water, by carrying an amulete secretly or 
by using garlic. Even though believing in superstitions is in contradiction with orthodox religion, local priests see them as traditions and do not try to change people's perception about their way of life ("I believe this is the house's custom. I do nothing, because I might alienate them from the church", $\mathrm{R}_{\mathrm{m} 56}$ ).

The most important moments in the Hutsuls's life are the same as those of the Romanians: birth, wedding and death. Wedding is the result of the family talks regarding the most suitable partner ("Father decided whom to marry", $\mathrm{H}_{\mathrm{f} 64}$ ). In the past, when a lad was convinced that the girl he courted was a good homemaker, he would send a man of honour "to go for the word", that is to ask her parents for permission to marry their daughter. As soon as the girl accepted the proposal, the families made the arrangements for the engagement ceremony, which took place either on a Saturday or on a day of celebration. On this occasion, the parents of the young people who were to marry discussed the dowry and established the house where the wedded pair would live (in case the lad did not already have one), as well as making an individual contribution to the wedding expenses.

In the end, the bridegroom's relatives supplied the drink, while the hosts laid the food on the table and the party began. In the past, but not so frequently today, the bridegrooms wore the Hutsul traditional costume, specially made for the event. The bride was wearing the wedding Cordalys garland with coloured ribbons. The grooms's wedding shirt was hand-sewn previously by the bride. The groom would come to his bride's house on the back of a horse adorned with coloured ribbons and having fir twig garlands around its neck. He was accompanied by druşte [maids of honor] and vătăjei [best men]. From the canvas supplied by the bride, druştele [the maids of honor] sewed năfrămi [kerchiefs], which they offered as a token of reward to the vătăjei [best men] who accompanied them to the wedding.

Even today, the bride's house is the scene of a series of customs marking the separation from family home and the forgiveness and blessing of the parents. The gates of the wedded couple's houses are adorned with small fir trees, 60-70 cm tall, of which hang coloured ribbons, because for the Hutsuls the fir tree is the symbol of power, longevity and wealth. In case the bride was from a neighboring village, groups of unmarried young people would block the road to the church with fir branches or logs, asking the groom to give them drink in exchange for clearing the way and let them pass. Nowadays, this custom called brama [the gate] is either extinct or extremely rare. 
The funeral ceremonies recall Dacian traditions (Grumezea 2009) because, apart of the orthodox religious customs, the atmosphere is dominated by happy moments (José Blanco and Vidal 2015) in accordance with the age of the deceased person, except for the young. If the deceased was an old man for whom death was a natural event, young people and children would lighten the moods with all kind of games (ciuşca or bâza [slapping game] and lapte gros [a game in which people jump on the other people's backs]). Likewise, they used to play costumed skits or to make jokes, which were meant to chase away the evil spirits and to ease the relatives' pain. The deceased made his or her last journey to the church and then to the cemetery in a cart pulled by oxen or horses having four fir trees at its corners.

Birth and christening are not different from the orthodox Romanian customs.

Folk ethos is preserved in songs and legends, which are passed to the descendents in an informal way because "şezătorile [villagers' gatherings] no longer occur" $\left(\mathrm{H}_{\mathrm{m} 64}\right)$, or through the agency of local bands $\left(\mathrm{R}_{\mathrm{m} 44}, \mathrm{H}_{\mathrm{m} 24}\right)$. The songs are assumed by the young people, who disseminate them through various cultural activities $\left(\mathrm{H}_{\mathrm{f} 18}\right)$. The same is done by those adults and elders who are members of the folk groups supported by their local or regional authorities (Fig. 4).

Figure 4. Youth Day in Paltinu Village, 2015 (Photo: Priest Coca Hancea Victor)

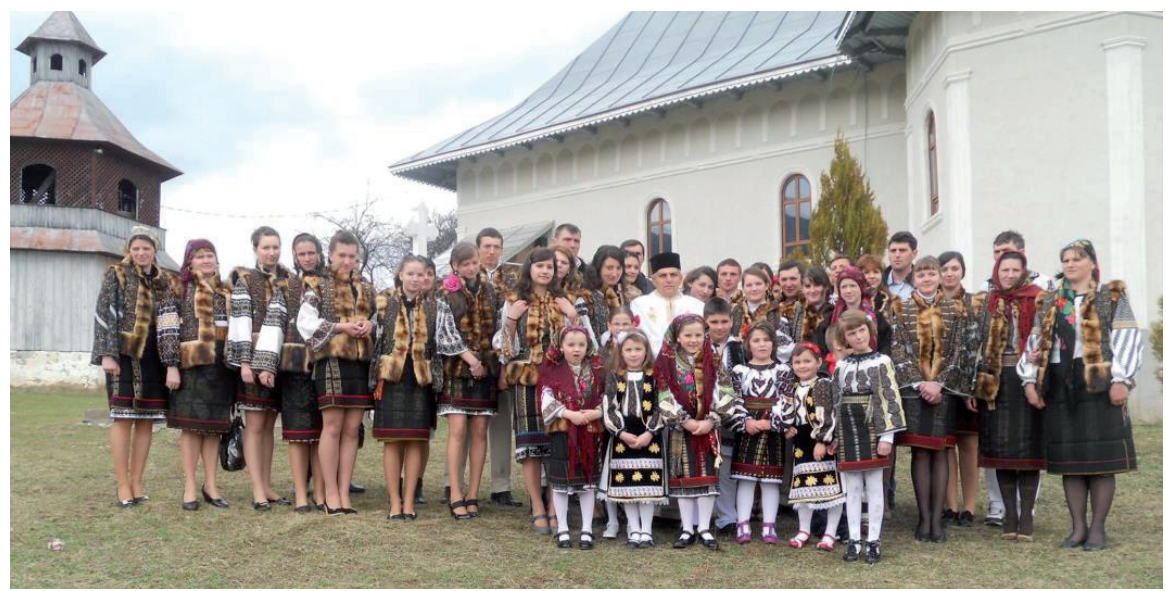


An interesting and sustainable initiative was found in the Modovița Commune, where the local priests have established the Youth Day, celebrated on the first day after Easter, when all the Hutsuls are invited to a compex religious and cultural show staged by young people dressed in folk costumes ("This is a good opportunity for making friends and for closing relationships that will usually last for the whole life", $\mathrm{H}_{\mathrm{m} 56}$ ).

All interviewees were proud of their Hutsul identity, even though confusions sometimes occur, as people think they are Ukrainians. These confusions arise from the fact that lately they have been involved in cultural exchanges under the umbrella of the the Association of the Ukrainians in Romania. This information is at odds with the Romanian education system, according to which these people learn the Ukrainian language as a discipline from their first class in primary education until the twelve grades, as this language has different words and accents. There is a concern regarding assimilation with the Ukrainian in the context that they agree the language is oral, "a mixture of Polish, Ukrainian, Romanian, even German and Hungarian words" $\left(\mathrm{H}_{\mathrm{f} 75}\right)$ without writing rules, being aware that their spiritual and cultural customs are unique. There are even monographies about this community, written in Romanian, or in Ukrainian to be promoted in both countries. Several initiatives of natives to establish a written form of Hutsuls language based on Latin alphabet generating online dictionaries, poetries, jokes, legends etc. Moreover, no-one has expressed the desire to become a nation like the other small nations in the European Union (Ross 2011).

The identity of the Hutsul ethnic group, assessed by monitoring the endogenous and exogenous perception have revealed the importance of the online environment in defining the ethnocultural characteristics of this minority, established since ancient times in the northern part of Romania.

The comments collected from the web (online media and socialmedia) have the following composition: $35.3 \%$ belong to the Hutsul ethnics (endogenous perception) and the rest of $64.7 \%$ to the Romanian ones. We accessed 35 web-sites with references to the Hutsul race, but comments on this subject were found only in seven of them ${ }^{1}$ which is a confirmation of the

1 http://www.natgeo.ro; http://www.ziarulstefancelmare.ro; http://adevarul.ro; http://flaviusobeada.wordpress.com; https://video.monitorulsv.ro; http://ioncoja.ro; http://www.gandul.info 
fact that these people are little known to the Romanian population. At the same time, the people belonging to this minority have a low contribution in promoting their origins and customs or their way of life in general.

As far as the ethnicity of Hutsul are concerned, they make comments on the origins of the ethnocultural group they belong to, on their way of life, and on their relationship with the Romanians or with other ethnic groups. Some of them consider themselves to be an "ethnicity of Slavicized northern Dacians", but others think the "Hutsuls speak a different Slavic language, akin to the Ukrainian one".

Casian Balabaşciuc (2006) is often cited by the media, because he said, "Hutsuls are the orphan children of history" because, like the Dacians, they are not aware of their origins. In his opinion, another similitude between these two ethnic groups is the lack of a written history, showing his fear, doubt about the security of "preserving their identity and the memory of their ancestors or for cultivating their origins". The same author considers the ethnic group of which he belongs as being weak; not economically, but in a cultural and spiritual sense, because it lacks the capacity to preserve its own identity on a long term.

In the field, however, people think that Hutuls are a strong group with a clear identity and that they are favoured by legislation. Moreover, they have many rights supporting personal development and the progress of their community $\left(\mathrm{H}_{\mathrm{f} 18}, \mathrm{H}_{\mathrm{m} 18}\right)$.

A representative of the Hutsuls have emphasised the communication and the relational skills of these people, which are tolerant of other ethnic groups. Likewise, they are somehow resigned and this fact is suggested by the comments of one of the interviewed subjects on the asssimilation tendencies that have culminated with their total assimilation by the Romanians or Ukrainians: "I believe that when my son introduces himself by saying 'I am a Hutsul, a member of a race threatened with extinction' he actually says everything". This explains the call released in the virtual environment to support the Hutsuls, a people on the verge of extinction, to preserve their language and culture.

Despite our findings in the field that traditions are preserved, people deem that several ancestral customs are abandoned. This happens, for instance, with religious practices which have been replaced by newer ones, borrowed from the Romanians (the Slavic religious service has been replaced by the Romanian one). 
We should emphasise that exogenous opinions are much more numerous than the endogeneous ones. It is worth highlighting the fact that many Romanian ethnics sympathise with the Hutsuls, appreciating their attitude, traditions and folk costumes ("The Hutsuls are wise and reliable. Romanians have learned a lot from them"; "The Hutsuls really deserve more attention"; "They are lively people who love their community, their games and traditions, as well as their tales with stray souls"). People generally fear that the globalisation phenomenon will erase their ethnic identity.

The exogenous comments are full of appreciative comments, people considering that Hutsul ethnicity has a lot to show to the world, but the people who can turn to accounting for the customs and artistic achievements of this community are rare.

Some argue that this ethnic group is confronted with an identity crisis and that the main cause for this reality is the globalisation phenomenon and the fracture that exists between the contemporary people and the former free people of the forest. These two causes are at odds with the right of every human being entitled to freedom, development and high living standards.

Unfortunately, we have also identified hostile attitudes towards the Hutsuls (although not so many), consisting in ironies, opposition to their ethnocultural affirmation or invitations to exhibit their customs and language in the Slavic countries.

\section{Threats and solutions}

In Romania, Hutsuls are not an ethnic group largely known to people, excepting those with higher education or interested in folk, science and tourism in this area. They are often lumped in with the Ukraine minority of Romania and never with Poles or Ruthenian from nearby region. In Suceava county they are both recognised and appreciated, largely perceived as being concentrated in northern area on Suceava Valley where the villages toponimy sounds tipically hutsuly (Brodina-Ehrişte, Zalomestra, Cununschi, Dubiuşca; Ulma-Lupcina), then in Moldovița Valley (Demăcuşa, Raşca, Argel and Paltinu, Ciumârna) and upper Moldova (Modova Sulița, Breaza), and a few in the Southern part $\left(\mathrm{R}_{m 64,} \mathrm{R}_{f 45,} \mathrm{H}_{m 60}\right)$. Their number seems to be in regression both spatially from north to south of Bucovina and temporally due to the mix family with Romanians and youth migration in Europe after 1990. 
Despite the opinions regarding good relations among Romanians and Hutsuls as the biggest minority of these villages, in schools, families, there have been several complaints about disrespect recorded downstream of the Modovița Valley. This lead us to conclude that there is a fear on the part young people who, at first discussion, do not recognise affiliation, except when they feel interest about their origins become communicative and pride in their ethnicity. People are afraid about their future as the members of the survey sample expressed their concern for the loss of traditional costumes, language, wood processing techniques and the traditions concerning the winter holidays. What menaces the Hutsul community from this point of view are the migration of the labour force and the invasion of the cheaper goods, which are not the result of their skilled work. At present, there are no workshops or households remaining to preserve the art of sowing and weaving the traditional costumes.

Carpentry, like weaving, is now practiced by only a few elderly people. The invasion of allochthonous products has brought about changes that have affected both the craft and the way the people decorate their homes. At the same time, under the influence of those who went abroad, while the fashion in house architecture has changed. The old houses where the elder families live are the only ones that preserve the Hutsul elements, while the traditional objects are either disposed of or preserved by the family members who, unfortunately, neither use them nor put them in sight.

However, people are optimistic about the songs, the dances and the egg painting techniques. These are disseminated through local programs, music bands, local or regional museums (Suceava, Bucharest) and Hutsul festivals held in Ukraine and Romania.

Valorification through business is still weak. The Easter painted eggs are most profitable which have become a source of income for few families. The horse breeding center in Lupcina represents a milestone for preserving Hutsul race $\left(\mathrm{H}_{m 45}\right)$, falling with few guesthouses in promoting tourism to this ethnic group and with Mocănița (narrow gauge train) the Hutsulca on Modovița valley. In fact, their position in the tourist region of Bucovina monasteries with medieval fresco painted exterior could be beneficial and not ccompetitive.

Moreover, in linking with cultural heritage of highlanders promoted in Carpathians or through their involvment in Via Carpathia, Romania could help in the creation of a cross-border nature park designed to preserve and 
exploit this fabulous potential inline with EU policy for multiculturalism. Such involvement may diminish the perception at this time, owing to a lack of awareness of the fact that tourism could help them preserve their traditions and enhance community revenues.

\section{Conclusions}

As the subject of this study, the Hutsul ethnic group of the South Bukovina province Romania is a part of highlanders in Carpathians area crossborder to Ukraine, spread in ten communes from Suceava county. Its number is unknown, being included in Ukrainian minority group in Romania, but generally it is perceived to suffer a regression due to mixeed families and youth migration presenting a unique and still unsolved history. This group has had contacts with different people and its cross-history besides Ukraine and Poland or later under the influence of the Austrian-Hungarian Empire and then dwelling on the Romanian territory. It has suffered acculturation phenomena, acquiring a unique language which has raised many controversies. These influences are also mirrored by the traditional costume and by their ethos. At the same time, historic difficulties and the elements of the environment explain their feelings related to superstitions, the melodic lines or the sad lyrics. However, their persistence in this mountain area has created a strong connection with nature, which is mirrored by their occupations, by their architecture and by their everyday life. The households have always observed empirical sustainable principles, which are now officially promoted by the European and the national economic, social and public policies.

In local perception both Hutsuls and Romanians recognised their unicity regarding some agricultural practices, food, wood processing, folk costume, songs and poetry, and several religious habits which must be preserved. On age groups, perceptions are contradictory. The elders are more conservative and slightly hostile against the changes brought after 1990, which encouraged migration of the labour force and the invasion of the cheaper goods, which compete with the traditional ones. On the other hand, young people are more open to the integration of the new realities in contemporary Hutsul society. Thus, they militate for finding appropriate solutions for turning to account the Hutsuls' traditional values through cultural events and tourist infrastructures 
(museums, workshops, etc.); in other words, initiatives that may ensure the promotion and sustainability of the Hutsul ethnics in Bukovina.

But, at the moment, we agree that "ongoing acquisition of new political, socio-cultural and economic models of life", in Hutsuls societies and those resembling them, including neighbourhoods "there can be observed a regression of tradition, customs and norms for the last decades" (Bucher and Nováková 2015). In this respect, the Hutsuls of South Bukovina should be assisted by local, national and regional authorities to solve all the controversial challenges facing them: in preservation of their traditions, including language and to adapt; approving new youth trends regarding education; and modernisation through more actions inside and within the transboundary area. Beyond the necessary cultural exchanges, they need to find economic approaches that persist in the long term, one of these being an emphasis on tourism which can have many benefits in all aspects of life.

\section{Acknowledgements}

The authors wish to thank a group of volunteers, students of the Dragoş Vodă High School and inhabitants of Hutsul villages, who did a great job in assisting us during the field observations, among whom Cotlarciuc Ioana Gabriela, Reapschi Mihăiță and Fercal Liviu Constantin stood out in particular. Likewise, we are indebted to the Hutsul people, the local authorities and especially the priest Coca Hancea Victor.

\section{References}

Adler, P.A., Adler, P. 1994 'Observational Techniques' in N. K. Denzin \& Y. S. Lincoln (eds) Handbook of Qualitative Research, Thousand Oaks: CA: Sage Publications. Andronic, M. 1998 'Hutsuls a minority in Buckovina' (Hutulii o minoritate in Bukovina), in Pagini din Istoria si Cultura Bucovinei, Soc. Culturală „Stefan cel Mare", pp.96.

Balabaşciuc, C. 2006 Stranger Hutsul Stories (Stranii povestiri huțule), Moldovița: Editura Cibela, pp. 236.

Bănățeanu, T. 1975 Bokovineean Folk Art (Arta populară bucovineană), Bucuresti: Editura Artis, pp. 332.

Bernard, H. R. 2000 Social research methods, Thousand Oaks: CA: Sage, pp.178. 
Bertaux, D. 1981 'From the life-history approach to the transformation of sociological practice' in D. Bertaux (ed.) Biography and Society: The life History Approach in the Social Sciences, London: Sage, pp. 29-45.

Bobocu-Cojocaru, A. 2010 'Huțulii din Bucovina - Controverse identitare', Constelații ieșene anul V,

4(20): 42-46.

Bucher, S. Nováková, Š. 2015 'Territorial Aspects of Regional Identity and Respondents' Identication with the Region and Place: Case Study of Slovakia, Eastern European Countryside 21: 81-109.

European Council 1995 Framework Convention for the Protection of National Minorities, Stasbourg: 3-4.

Figlus, T. 2009 'Past and present of Hutsulshchyna as the Carpathian borderland region. Remarks on changes of spatial structures, ethno-cultural specificity and heritage', Region and Regionalism Vol. 9, pp.143-159.

Grumezea, I. 2009 Dacia: Land of Transylvania, Cornerstone of Ancient Eastern EuropeHamilton books, p.77.

Guest, G., Bunce, A. \& Johnson, L. 2006 'How many interviews are enough? An experiment with data saturation and variability', Field Methods 18: 59-82.

Huțuleac, D. 2014 'Despre originea, limba şi cultura etniei huțule în contextul globalizării’, in Memoria ethnologica no. 50-51 (An XIV), Maramureş.

Iosep, I. 1999 'Economic-geographic study of Bukovina Mountain' (Studiul geografico-economic al Obcinelor Bucovinei), Teza de doctorat, Universitatea Al. I. Cuza, Iasi, p. 365.

Irimie, R.C. 2014 'Religion and political identification in Communist Romania', Revista POLIS Vol. II 2 (4): 44-66.

José Blanco, M. \& Vidal, R. 2015 The Power of Death: Contemporary Reflections on Death in Western Society, New York-Oxford: Berghahn.

Marian-Bălaşa, M. 2013 'Maternity as a source of religion', Journal of Ethnography and Folklore 1-2: 101-108.

Matei, E., Dumitrache, L., Manea, G., Cocoş \& O., Mihalache, C. 2013 'The Begging Phenomenon in Bucharest City: Dimensions and Patterns of Expression', Revista de cercetare şi intervenție social 43: 61-79.

Morse, J. 1994 'Designing funded qualitative research' in N. Denzin \& Y. Lincoln (eds) Handbook for Qualitative Research,Thousand Oaks: CA: Sage: p. 225.

Murthy, D. 2013 Twitter: Social Communication in the Twitter Age, Cambridge: Polity, pp. 7-8

Nikitin, A.G., Kochkin, I.T., June, C.M., Willis. C.M., Mcbain, I. \& Videiko, M.Y. 2009 'Mitochondrial

DNA sequence variation in the Boyko, Hutsul, and Lemko populations of the Carpathian highlands', Human Biology 81(1): 43-58. doi: http://dx.doi. org/10.3378/027.081.0104. 
Nimigeanu, Gh. 1945 Hutsans from Bukovina-Antropogeographic and ethnograhic study (Huțanii din Bukovina - Studiu antropogeografic şi etnografic), Teză de doctorat, mss, col. Prof. P. Froicu, Suceava.

Nistor, I. 1915 'Românii şi rutenii în Bukovina', Studii istorice şi statistice XX/1914, Bucureşti.

Population and Housing Census of Romania 2011. Available http://www.insse.ro/ $\mathrm{cms} / \mathrm{ro} /$ content/diseminare-informatii-statistice (January 2016).

Ross, A. 2011 'Border Crossing Young People's Identity in Time of Change', in C. Mesaroş (ed.) Knowledge Communication: Transparency, Democracy, Global Governance, West Timisoara University Publishing House, pp.65-82.

Sõukand, R. \& Pieroni, A. 2016 'The importance of a border: Medical, veterinary, and wild food ethnobotany of the Hutsuls living on the Romanian and Ukrainian sides of Bukovina', Journal of Ethnopharmacology 185: 17-40.

Small, M. L. 2009 'How many cases do I need? On science and the logic of case selection in field-based research', Ethnography 10: 5-38.

Tufescu, V. 1970 On Modova Valley (Pe Valea Moldovei), Bucureşti: Editura Ştiințifică.

Tîrcomnicu, E. 2013 'Identity and self-identification of Aromanians and MeglenoRomanian in Dobrogea, Journal of Etnography and Folkore, New Series 1-2: 217-236.

Vasilcu, D. 2006 Moldova Valley in Carpathian Sector. Human geography Study (Valea Moldovei în sectorul carpatic. Studiu de geografie umană), Suceava: Universității Publishing House, pp. 343.

Warren, C. A. B. 2002 'Qualitative Interviewing', in J. F. Gubrium \& J. A. Holstein (eds), Handbook of Interview Research: Context and Method, Thousand Oaks: CA: Sage, pp. 83-101.

http://www.natgeo.ro (accessed in February 2016)

http://www.ziarulstefancelmare.ro

(accessed in February 2016)

http://adevarul.ro (accessed in February 2016)

http://flaviusobeada.wordpress.com (accessed in February 2016)

https://video.monitorulsv.ro (accessed in February 2016)

http://ioncoja.ro (accessed in February 2016)

http://www.gandul.info (accessed in February 2016) 